\title{
Scab resistance in Malus sp. progenies - inheritance and resistance stability
}

\author{
G. Tóth, M., Kovács, Sz. and D. Rozsnyay, Zs. \\ Department of Fruit Science, Faculty of Horticulturae, Szent István University \\ H-1118 Budapest, Villányi út 35-43.
}

\begin{abstract}
Summary: Susceptibility of progenies of some Malus species to apple scab was evaluated. Susceptibility of hybrid families was observed first in greenhouse after artificial inoculations by the suspension of the pathogen, Venturia inaequalis (Cooke) Wint., then in open field. The Hungarian type of Malus floribunda, which proved to be scab resistant in our examinations, has a positive effect on the segregation of progenies to resistant and susceptible individuals as a male parent, not depending on the rate of susceptibility of the other parent. However, the German type of Malus floribunda and Malus prunifolia act as dominant, highly susceptible parents.

Malus $x$ purpurea and Malus baccata, which proved to be highly susceptible to apple scab in open field and in artificial inoculations, transmits its susceptibility only slightly to its progenies as a male parent.

According to our experiments, the inheritance of scab resistance of Malus floribunda cannot be considered as monogenic, as published by other authors.

Scab susceptibility of parents influences the segregation of progenies to resistant or susceptible individuals. The moderately scab susceptible 'Idared' as female parent has a statistically proved positive effect on the segregation of its progenies.

More factors indicate the appearance of a new race of Venturia inaequalis (Cke.) Wint.: change of the symptoms in the greenhouse; considerable increase of susceptible individuals after greenhouse inoculation in 1997; more and more progenies of the male parent Malus floribunda became susceptible to scab in open field.
\end{abstract}

\section{Key words: Malus, Idared, apple, scab, resistance, inheritance}

\section{Introduction}

The aim of our new apple breeding program started in the beginning of the 90 s at the Department of Pomology, is to create productive and high quality apple varieties with resistance to most important diseases of apple (apple scab, powdery mildew, fire blight) (G. Tóth et al., 1994). In this program special attention was paid to examination of inheritance of apple scab resistance.

Breeding a resistant variety is some kind of racing with new races of the pathogen. According to present knowledge, the pathogen Venturia inaequalis (Cooke) Wint. has more than seven races (biotypes), and scab resistant varieties have different susceptibility to different races of the pathogen (Parisi \& Lespinasse, 1996; Krüger, 1999; Schärer \& Kellerhals, 2000; Fischer C. et al., 2000; Bénaouf \& Parisi, 2000).

Till present the most important gene source of resistance breeding was Malus floribunda with $\mathrm{V}_{\mathrm{f}}$ gene. Inheritance of $\mathrm{V}_{\mathrm{f}}$ resistance was considered to be monogenic at first (Lamb \& Hamilton, 1969), but then it was found that not only one gene is responsible for the resistance. It is likely that there are modifying, supplementing genes in the presence of $V_{f}$ gene (eg. $\mathrm{V}_{\mathrm{f}}$ and $\mathrm{V}_{\mathrm{fh}}$ ), or individual genes with minor effect (Gessler, 1992; Kellerhals et al., 1993; Parisi et al., 1996; G. Tóth et al., 2000), but there remained some questions to answer about genetic background of inheritance.
Breeders are looking for new gene sources of secure and durable resistance (Alston, 1994; Fischer C. et al., 2000; Kellerhals et al., 1998). Especially gene sources of resistance to more pathogens (apple scab, powdery mildew, fire blight - multiple resistance) are valuable for resistance breeding (Alston, 1994; Janick \& Moore, 1996; Kellerhals et al., 1998; Fischer C. et al., 2000).

Only a few of the 400-500 taxa in Malus genus can serve as a gene source for resistance breeding. Utilizable gene sources are mostly from sections and series in close relationship to Malus $x$ domestica (Pumilae, Baccatae, Sieboldianae). Breeders suppose that resistance of closely related species is probably based on the same gene, therefore it is advisable to concentrate on species from other sections to create a wide and secure genetic base for commercial varieties (Büttner et al., 1999).

From the Malus collection of the Dresden-Pillnitz Research Institute an old-new source of resistance was chosen: Malus sylvestris (Linn.) Mill., which is widespread in Europe, shows good resistance to more pathogens and transmits this resistance to its progenies. Valuabłe breeding material was found in some sections of distant relationship to Malus $x$ domestica (Cloromeles, Sieboldianae, Kansuenses). However, their widespread utilization is hindered because of fertility problems (Büttner, 1999, Büttner et al., 1999). 
According to our former examinations, some taxa having outstanding resistance not only to apple scab, but to powdery mildew as well, can serve as new gene sources (Malus fusca, $M$. halliana, $M$. spectabilis és a $M$. spectabilis 'Van Eseltine'). Some natural seedlings of $M$. baccata and some individuals of $M$. floribunda and $M . x$ zumi are also worth mentioning (Kovács \& G. Tóth, 2002).

In our present work we demonstrate the apple scab resistance of progenies originating from crossings of different Malus species from Hungary and from DresdenPillnitz as male varieties, and highly susceptible ('Gloster') and moderately susceptible ('Idared') apple varieties, according to Hungarian literature (G. Tóth, 1997, Soltész, 1998), as female varieties, as well as the temporal variation of this resistance. We tried to answer the following questions:

- What kind of differences are there in the distribution according to susceptibility grades of progenies of Malus species and types combined with 'Idared' female parent (moderately susceptible), and in the transmission of scab resistance?

- Do susceptible varieties, combined with Malus floribunda male parent, have a role in transmitting resistance?

- Is there any correlation between the resistance of parent varieties after artificial inoculation and the transmission to progenies?

- Is there any difference between the resistance transmitting effect of German (Dresden-Pillnitz) and Hungarian (Buda Arboretum) types of Malus floribunda?

- Is there any change in the manifestation of symptoms indicating susceptibility after inoculation in greenhouse with pathogen populations from different years?

- Have the virulency and the natural Hungarian biotype of the pathogen changed in the nineties?

\section{Material and method}

Crossings were made in 1993 and in 1996 on trees of 'Idared' and 'Gloster' female varieties. Pollens of male varieties originated from the Buda Arboretum of the University in the case of Malus baccata, Malus floribunda and $M$. x purpurea, while pollens of $M$. prunifolia, $M$. floribunda and $M$. micromalus were given by Büttner from Dresden-Pillnitz. Resistance of Hungarian parent varieties were examined on 4-4 grafts/M9 rootstock.

2-3-leaf seedlings of progenies were inoculated in greenhouse with the suspension of Venturia inaequalis (Cooke) Wint. in 1994 and in 1997. After greenhouse forcing, shoots of parent variety grafts were artificially inoculated in phytotron in 1996 and in 1997, or in greenhouse in 2000 and in 2001. For inoculation we used a $4-4,5 \times 10^{5}$ conidiums $/ \mathrm{ml}$ suspension in 1994 , and a $2-2.5 \times$ $10^{5}$ conidiums/ml suspension from 1995. In 1994 the pathogen used for inoculations was collected a couple of years before. The material was held on potato dextrose culture, and was activated and propagated before inoculation. In later years the inoculum contained the Hungarian natural Venturia inaequalis (Cooke) Wint. population from preceding years. During three days of incubation a temperature of $18-20{ }^{\circ} \mathrm{C}$ and a humidity of $90 \%$ was held under plastic. During post-inoculation the temperature was $20-22{ }^{\circ} \mathrm{C}$, the humidity $70 \%$ at least. Inoculations were repeated after 12-14 days.

In greenhouse examinations, evaluation of susceptibility to venturia scab was carried out 4 weeks after first inoculation. In 1994 we used the evaluation method of Hough et al. (1953): $0=$ no visible symptoms, $1=$ small, pinpoint lesions, 2 = chlorotic lesions without sporulation, $3=$ few restricting sporulating lesions (on less than $25 \%$ of leaf surface), 4 = abundant sporulation. In this year we detected some symptoms which cannot be identified by susceptibility grades.

From 1995 we could identify the symptoms more precisely using the cathegories of Chevalier et al. (1991): $0=$ no visible symptoms, 1 = pinpoint spots, 2 = chlorotic lesions and/or leaf wrinkling without sporulation, 3 = various symptoms: chlorotic spot and/or leaf wrinkling with weak sporulation, necrotic spots with or without sporulation, including $3 \mathrm{~A}=$ huge number of living stromata with moderate sporulation, and $3 \mathrm{~B}=$ visible chlorotic and necrotic 'lesions with sporulation, $4=$ numerous conidiophores often grouped in clusters and sporulating abundantly.

In both cases only individuals of cathegory 4 were considered to be susceptible, these and retarded individuals were destroyed. Hybrids found resistant in greenhouse in 1994 were grafted to yielding 'Starkrimson' trees on M4 rootstock in 1995 for further examinations, while seedlings sown in 1997 were bred in nursery density conditions from June.

In open field examinations we evaluated scab resistance in June and September according to the following two grades: $\mathrm{S}=$ visible sporulation on leaves (susceptible), $\mathrm{R}=$ no sporulation on leaves (resistant). Open field and greenhouse results were put together, and the proportion resistant and susceptible individuals were calculated from these aggregate data.

We used $\chi^{2}$ test for evaluation of data concerning hybrids. Segregation of progenies to different susceptibility cathegories and to resistant and susceptible groups (aggregate data) was interpreted according to the same female or male, and was compared to each other in pairs. If the calculated $\chi^{2}$ value was less than the standard, the two examined distributions were considered to be homogenous, in any other cases they were considered to be different. Using this method we can determine, how the parent in question transmits apple scab resistance or susceptibility to its progenies. From segregation rates (resistant : susceptible) we can draw a conclusion about genetic determination.

\section{Results}

From the results of artificial inoculations in greenhouse with the suspension of the pathogen Venturia inaequalis 
(Cooke) Wint. in 1994 and 1997, it is visible that segregation of Malus progenies to susceptibility cathegories differs highly in the two years of examination. In 1994 the rate of seedlings in cathegories 1 and 4 was the highest, while in 1997 the rate of cathegories 3a, 3b and 4 was the first (Table I, Figure 1). seedlings of these two hybrid families to scab susceptibility cathegories does not show any difference.

A number of seedlings proved to be resistant in greenhouse were contaminated later in the open field (Table 2). Most of natural scab contaminations took place $2-3$ years after planting. According to our results, scab resistance of

Table I Distribution of progenies to scab susceptibility cathegories on the basis of greenhouse and open field examinations (1994, 1997)

\begin{tabular}{|c|c|c|c|c|c|c|c|c|c|c|c|c|c|c|}
\hline \multirow[t]{3}{*}{$\begin{array}{l}\text { Female } \\
\text { partner }\end{array}$} & \multirow[t]{3}{*}{$\begin{array}{c}\text { Male } \\
\text { partner }\end{array}$} & \multirow{3}{*}{$\begin{array}{l}\text { Number } \\
\text { of plants } \\
\text { in tests }\end{array}$} & \multicolumn{6}{|c|}{$\begin{array}{l}\text { Seedlings in scab susceptibilty } \\
\text { cathegories }(\%)\end{array}$} & \multicolumn{2}{|c|}{$\begin{array}{l}\text { Greenhouse } \\
(\%)\end{array}$} & \multirow[t]{3}{*}{$\begin{array}{r}\text { Female* } \\
\text { Male* }\end{array}$} & \multicolumn{2}{|c|}{$\begin{array}{c}\text { Greenhouse+ } \\
\text { open field }(\%)\end{array}$} & \multirow[t]{3}{*}{$\begin{array}{l}\text { Female* } \\
\qquad \text { Male* }^{*}\end{array}$} \\
\hline & & & \multirow[t]{2}{*}{0} & \multirow[t]{2}{*}{1} & \multirow[t]{2}{*}{2} & \multicolumn{2}{|c|}{3} & \multirow[t]{2}{*}{4} & \multirow[t]{2}{*}{ resistant } & \multirow{2}{*}{ susceptible } & & \multirow[t]{2}{*}{ resistant } & \multirow[t]{2}{*}{ susceptible } & \\
\hline & & & & & & $3 a$ & $3 b$ & & & & & & & \\
\hline \multicolumn{15}{|c|}{ Progenies started to develop in 1994} \\
\hline Idared & $\begin{array}{l}\text { M. } x \text { purpurea } \\
\text { (BA) }\end{array}$ & 251 & 3 & 39 & 14 & & & 31 & 69 & 31 & - & 63 & 37 & g.i \\
\hline Gloster & $\begin{array}{l}\text { M. floribunda } \\
\text { (BA) }\end{array}$ & 245 & 11 & 35 & 12 & & & 30 & 70 & 30 & - & 55 & 45 & b \\
\hline Idared & $\begin{array}{l}\text { M. baccata } \\
\text { (BA) }\end{array}$ & 230 & 17 & 30 & 11 & & & 31 & 69 & 31 & g.i & 57 & 43 & f.h.i \\
\hline \multicolumn{15}{|c|}{ Progenies started to develop in 1997} \\
\hline Idared & $\begin{array}{l}\text { M. micromalus } \\
\text { (Pillnitz) }\end{array}$ & 22 & 9 & 0 & 5 & 22 & 23 & 41 & 59 & 41 & c.e.f.i & 54 & 46 & c.e.g.h \\
\hline Idared & $\begin{array}{l}\text { M. prunifolia } \\
\text { (Pillnitz) }\end{array}$ & 39 & 5 & 0 & 18 & 21 & 28 & 28 & 72 & 28 & $\begin{array}{l}\text { b.d.f.h } \\
\\
-\end{array}$ & 23 & 77 & b.d \\
\hline Idared & $\begin{array}{l}\text { M. floribunda } \\
\text { (Pillnitz) }\end{array}$ & 16 & 6 & 0 & 6 & 6 & 13 & 69 & 31 & 69 & $\begin{array}{r}\text { a.d.e.g } \\
\text { a }\end{array}$ & 31 & 69 & a.d.e.f \\
\hline Idared & $\begin{array}{l}\text { M. floribunda } \\
\text { (BA) }\end{array}$ & 128 & 4 & 0 & 13 & 12 & 30 & 41 & 59 & 41 & a.b.c & 42 & 58 & a.b.c \\
\hline
\end{tabular}

Notes: Letters in the column signed by * indicate similar distributions on the base of $\chi^{2}$ tests in case of the same parents on $95 \%$ probability level. 'Idared' $\times M$. floribunda (Pillnitz) progenies were observed only in greenhouse.

Origin of male partners used in crossings: $\mathrm{BA}=$ Buda Arboretum, Pillnitz=Drezda-Pillnitz.

The rate of resistant and susceptible individuals of progenies from the 1994 inoculation was 2:1 in greenhouse (Table 1). We experienced this rate in the case of the highly scab susceptible 'Gloster' and the resistant Malus floribunda (BA), the moderately susceptible 'Idared' and the highly susceptible Malus baccata (BA), as well as in the case of 'Idared' and the highly susceptible Malus $x$ purpurea (BA) parents.

The segregation of progenies from the 1997 inoculation in greenhouse to resistant and susceptible individuals shows considerable differencies. Among moderately scab susceptible parents, 'Idared' x Malus micromalus (Pillnitz), the result was $1: 1$, while a segregation rate of $2: 1$ was obtained in the case of 'Idared' $\times$ Malus prunifolia (Pillnitz) hybrid family. Segregation of progenies of Malus floribunda types from Buda Arboretum and from Dresden-Pillnitz to resistant and susceptibie individuals is also different, in case of the same female parent ('Idared'). The segregation rate of progenies of 'Idared' $\times$ Malus floribunda $(\mathrm{BA})$ parents is $1: 1$, while in the combination of 'Idared' $\times$ Malus floribunda (Pillnitz) it is 1:2 (Table 1). However, the segregation of progenies of 'Idared' $\times$ Malus micromalus (Pillnitz) seems to be the most secure, because only one individual got the illness during six years of examination. The greatest rate of open field contamination was observed at progenies evaluated in greenhouse in 1994, and at 'Idared' $\times$ Malus prunifolia (Pillnitz) progenies.

Therefore in the case of progenies started to develop in 1994, the rate of resistant and susceptible individuals changed from 2:1 to $1: 2$ in combinations 'Idared' $\times$ Malus baccata (BA) and 'Gloster' $\times$ Malus floribunda (BA). Among seedlings sown in open field in 1997, a significant increase in the number of susceptible individuals can be observed at the 'Idared' $\times$ Malus prunifolia (Pillnitz) combination. In this hybrid family the rate of resistant and susceptible individuals changed from $2: 1$ to $1: 2$. In other combinations the $1: 1$ segregation rate has not changed (Table 1, Figure 2).

The effect of the 'Idared' female parent-combined with certain highly susceptible Malus species (Malus $\times$ purpurea, Malus baccata), as well as with the susceptible and resistant type of Malus floribunda - to the segregation of its progenies can be statistically proved (Table 1, Figure 2). 

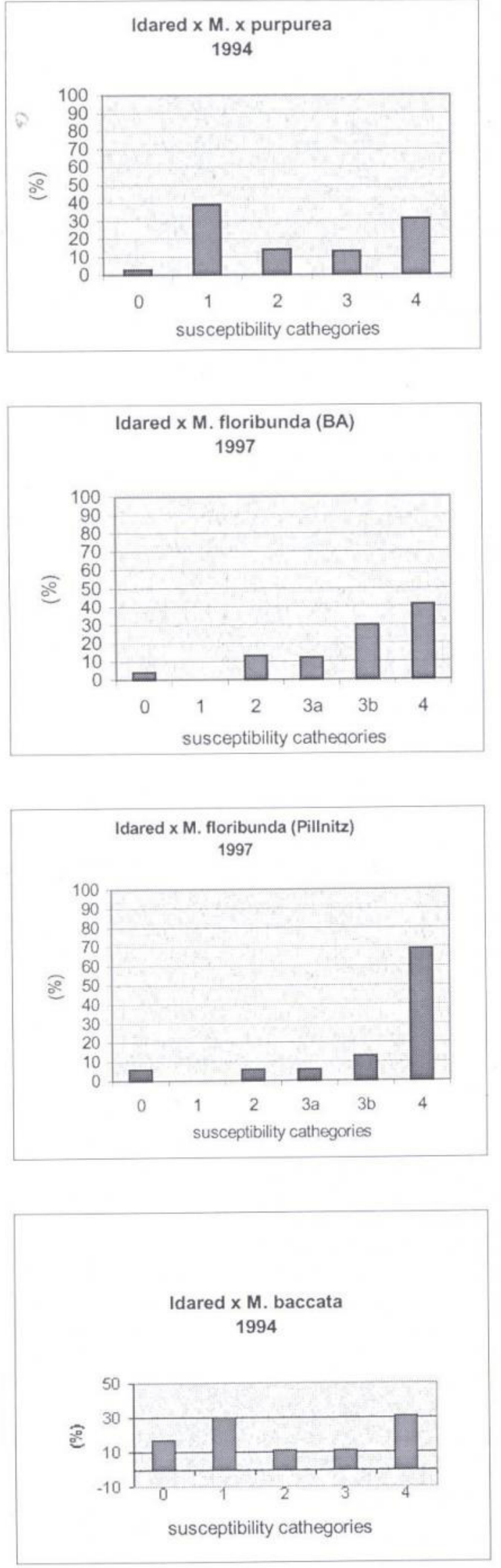

1 Figure Distribution of progenies to scab susceptibility in the greenhouse
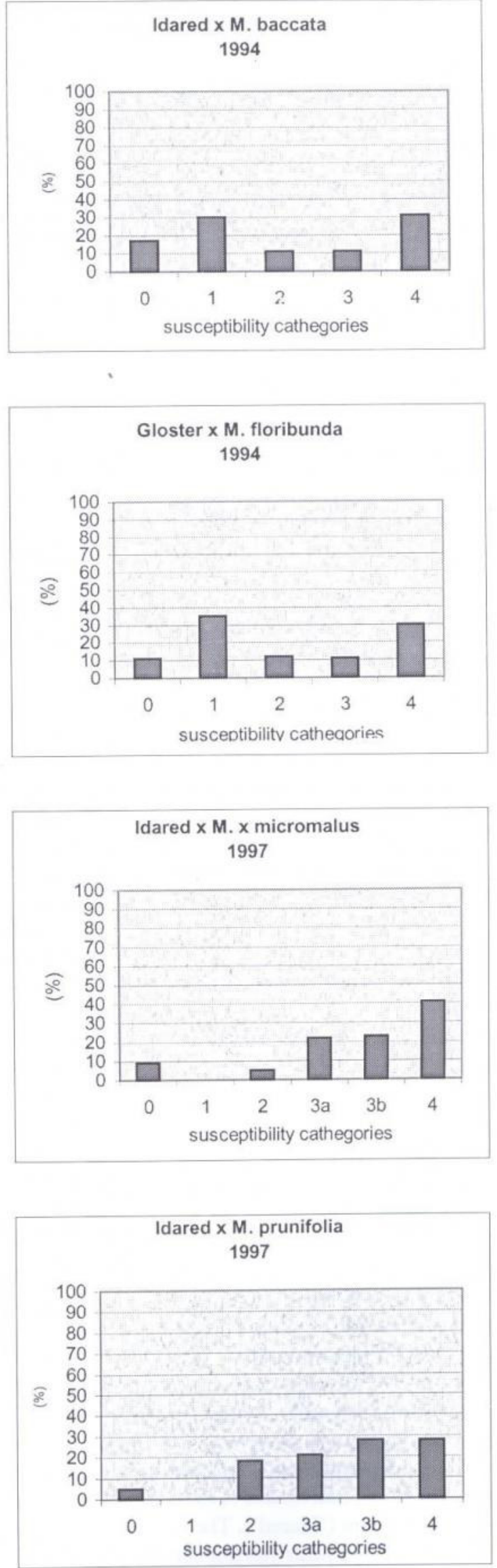
The Hungarian Malus floribunda type as a male parent had a favourable effect on the segregation of progenies to resistant and susceptible individuals, but this slighter effect cannot always be statistically proved. We cannot state this about the German type, in spite of the fact that we have only greenhouse data (Figure I).

Scab susceptibility of Hungarian Malus species used in crossings was evaluated in open field and after artificial inoculation (Table 3). According to our open field examinations of several years (1997-2001) and artificial inoculation results, Malus $\times$ purpurea proved to be highly susceptible to apple scab. In susceptibility of Malus baccata, significant differences can be observed between Hungarian types. In 1996 only one graft of the tree in Buda Arboretum could be contaminated in phytotron. Next year we observed severe contamination in open field, and this was repeated in later years as well. A type of Malus floribunda in Buda Arboretum proved to be resistant, but in spring we observed chlorotic spots and small deformations on leaves. Malus floribunda saved its resistance after artificial inoculation

Table 2 Rate of hybrids newly contaminated with scab in open field (Szigetcsép 1995-2002)

\begin{tabular}{|c|c|c|c|c|c|c|c|c|c|c|}
\hline \multirow{2}{*}{$\begin{array}{l}\text { Female } \\
\text { variety }\end{array}$} & \multirow{2}{*}{ Male variety } & \multirow{2}{*}{$\begin{array}{c}\text { Number of } \\
\text { planted seedlings } \\
\text { in open field }\end{array}$} & \multicolumn{8}{|c|}{ Number of new contaminations on planted seedlings in open field } \\
\hline & & & 1995 & 1997 & 1998 & 1999 & 2000 & 2001 & 2002 & $\begin{array}{c}\text { Total } \\
\%\end{array}$ \\
\hline ldared & M. x purpurea $(\mathrm{BA})$ & 45 & 7 & 5 & 0 & 4 & 1 & 0 & 0 & 38 \\
\hline Gloster & M. floribunda $(\mathrm{BA})$ & 87 & 17 & 5 & 6 & 5 & 1 & 3 & 0 & 43 \\
\hline Idared & M. baccata $(\mathrm{BA})$ & 46 & 7 & 14 & 1 & 5 & 2 & 0 & 0 & 62 \\
\hline Idared & M. micromalus (Pillnitz) & 7 & - & 0 & 0 & 0 & 0 & 1 & 0 & 14 \\
\hline Idared & M. prunifolia (Pillnitz) & 25 & - & 5 & 11 & 3 & 0 & 0 & 0 & 76 \\
\hline Idared & M. floribunda (BA) & 68 & - & 2 & 9 & 3 & 6 & 0 & 1 & 29 \\
\hline
\end{tabular}

Note: Hybrids highly susceptible to scab and powdery mildew were eliminated in September 1995, in June 1998 and in February 2002.

Progenies started to develop in 1994

Idared x M. baccat
Gloster x M. floribund
Idared x M. x purpurea

Progenies started to develop in 1997

$$
\text { Idared x M. prunifolia }
$$

Idared x M. floribunda

Idared $\times$ M. micromalus
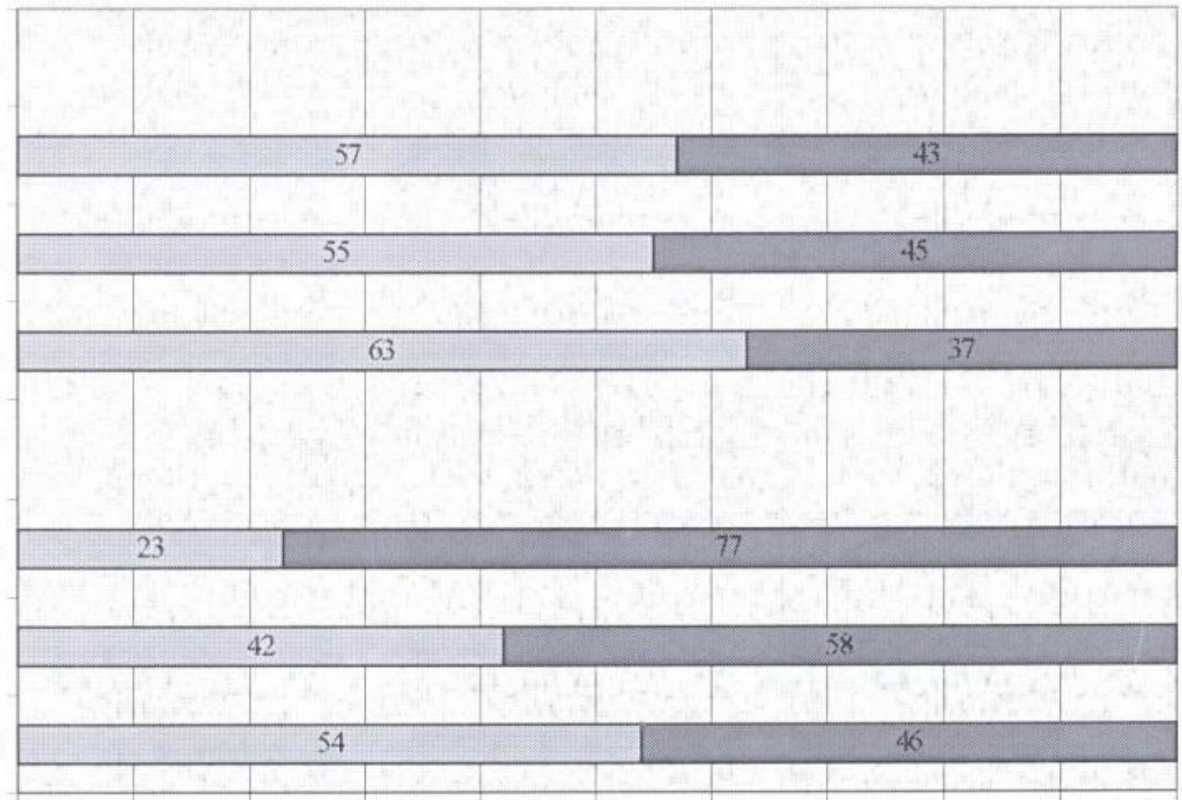

0

10

20

30

40

50

60)

70

80

90 100

$(\%)$

2 Figure Segregation of progenies to scab resistant and susceptible groups (Result of greenhouse and field examinations) 
Table 3 Scab susceptibility of species and varieties used as parents after artificial inoculations $(1995 ?, 2000,2001)$

\begin{tabular}{|c|c|c|c|c|c|c|c|c|c|c|}
\hline \multirow[b]{2}{*}{ Taxa } & \multirow{2}{*}{$\begin{array}{c}\text { Place of } \\
\text { production } \\
\text { and evaluation }\end{array}$} & \multirow[b]{2}{*}{ Susceptibility } & \multicolumn{8}{|c|}{ Susceptibility after artificial inoculation } \\
\hline & & & $\begin{array}{l}1996 . \\
05.20\end{array}$ & $\begin{array}{r}1996 . \\
06.03 .\end{array}$ & $\begin{array}{l}1997 . \\
06.12\end{array}$ & $\begin{array}{r}1997 . \\
06.25\end{array}$ & $\begin{array}{l}2000 \\
04.06\end{array}$ & $\begin{array}{l}2000 . \\
04.20\end{array}$ & $\begin{array}{l}2001 . \\
04.18 .\end{array}$ & $\begin{array}{l}2001 . \\
05.07 .\end{array}$ \\
\hline M. floribunda Sieb. & Buda Arboretum & resistant & $\begin{array}{c}2(3 a) \\
\text { leaf } \\
\text { deformations }\end{array}$ & $3 b(4)$ & $\begin{array}{c}2 \\
\text { leaf } \\
\text { deformations }\end{array}$ & 2 & $\begin{array}{c}2 \\
\text { leaf } \\
\text { deformations }\end{array}$ & 2 & $3 \mathrm{a}$ & $3 b$ \\
\hline M. baccata Borkh. & Buda Arboretum & $\begin{array}{c}\text { highly } \\
\text { susceptible }\end{array}$ & $2(3 b)$ & $3 a(4)$ & - & - & - & - & - & - \\
\hline $\begin{array}{l}\text { M. x purpurea } \\
\text { Rehder }\end{array}$ & Buda Arboretum & $\begin{array}{c}\text { highly } \\
\text { susceptible }\end{array}$ & - & - & - & - & $3 b(4)$ & 4 & - & - \\
\hline
\end{tabular}

experiments as well, but some leaf deformations and wrinklings were observed also in this case.

\section{Discussion}

Difference between the results of 1994 and 1997 inoculations can be explained by a couple of reasons. The less than expected susceptible individuals in 1994 - in spite of the higher concentration of Venturia inaequalis (Cooke) Wint. suspension - can be an effect of unfavourable weather conditions. However, the increase of susceptible individual rate in 1997 cannot only be explained by the optimal environment conditions for the pathogen Venturia inaequalis (Cooke) Wint., but probably by the fact as well, that the suspension of the pathogen could contain a new race in Hungary. The modifying effect of these factors are also proved in the experiments of Shay et al. (1953), Keulemans (1998) and Fischer C. et al. (1998).

The Hungarian type of Malus floribunda which, according to our examinations, proved to be resistant to the Hungarian suspension of the pathogen, transmitted the resistance well as a male parent, not depending on the susceptibility rate of the other parent. This corresponds to former results published in literature.

On the contrary, the Malus floribunda from DresdenPillnitz - in case of contamination by Hungarian Venturia population - acted as a dominant, highly susceptible parent, and the majority of individuals in its progenies became susceptible as well. Scab resistance of Malus floribunda was not permanent in Germany as well, because the $3^{\text {rd }}$ race of pathogen Venturia inaequalis (Cooke) Wint. has broken the resistance in 1994 (Fischer C, 2000).

According to literature data (Fiala, 1994), Malus prunifolia is moderately susceptible to venturia scab. However, on the basis of our results, speaking about using this species as a resistant parent, it can be stated that it is highly susceptible to the Hungarian population of Venturia inaequalis (Cooke) Wint., and transmits this susceptibility to its progenies.

Progenies of 'Idared' $\times$ Malus micromalus $(\mathrm{Vm})$ had the most secure resistance. This cannot be stated about certain progenies of the Hungarian Malus floribunda type (Vf), because more and more individuals became contaminated after planting out the seedlings. This indicates the appearance of a new race of Venturia inaequalis (Cooke) Wint. This more agressive race probably evolved in 1995-1996, two highly precipitated years. Propagation of hybrid populations produced in apple breeding program (grafting by approach to yielding 'Jonathan' and 'Starkrimson' trees on M4 rootstock) started in 1994. After this no fungicides were used in the orchard. In the orchard with grass in the rows ascospores could easily fall out from scabby leaves of susceptible trees. In favourable weather conditions in the young grafted population a new, higly agressive race of Venturia inaequalis (Cooke) Wint. could evolve in a short time, and it contaminates from then on (Fischer C. et al., 2000; McHardy, 1996).

Signs of change in the Hungarian biotype of Venturia inaequalis (Cooke) Wint. were already observed after artificial inoculations in 1993, 1994 and 1995. After greenhouse inoculation, we observed less symptoms of hypersensitive reaction on leaves of seedlings and the appearance of leaf-rolls ( $G$. Tóth et al., 1996). Another sign of evolving a new race is that in the Soroksár Botanic Garden the suspension of the pathogen from 2000 has broken the resistance of $\mathrm{V}_{\mathrm{f}}$ gene in Malus floribunda trees, and an increasing susceptibility was observed in the case of other species and varieties as well (Kovács \& G. Tóth, 2002).

According to our experiments, the inheritance of scab resistance of Malus florihunda cannot be considered as monogenic. In case of a monogenic inheritance the rate of resistant and susceptible individuals is 1:0 or 1:1, while we experienced different segregation rates as well, similarly to other authors (Gessler, 1992; Kellerhals et al., 1993; Parisi et al., 1996; G. Tóth et al., 2000).

Our artificial inoculation experiments in greenhouse and the results of open field observations confirm the statement of Kellerhalls et al. (1996) and G. Tóth et al. (1996), that scab susceptible parents can have an influence on the segregation of their progenies by susceptibility. According to our present results, the positive influence of the moderately susceptible 'Idared' - combined with different susceptibility Malus taxa - to the distribution of progenies can be statistically proved. 


\section{References}

Alston, F. H. (1994): Entwicklung neuer Apfelsorten. Obstbau. 5: 247-248.

Bénaouf, G. \& Parisi, L. (2000): Genetics of host-pathogen relationships between races 6 and 7 and Malus species. Phytopathology. 90: 236-242.

Büttner, R. (1999): Malus sylvestris (L.) Mill.-Eine potentielle Quelle für Mehltauresistenz in der Apfelzüchtung. Erwerbsobstbau. 41: 100-101.

Büttner, R., Geibel, M. \& Fischer, C. (1999): Das genetische Potential an Schorf- und Mehltauresistenz in Malus-Wildarten. Erwerbsobstbau. 41: 102-105.

Chevalier, M., Lespinasse, Y. \& Renaudin, S. (1991): A microscopic study of the different classes of symptoms coded by the $V_{f}$ gene in apple for resistance to scab (Venturia inaequalis). Plant Pathology. 40: 249-256.

Fiala, J. \& John, L. (1994): Flowering Crabapples: the genus Malus. Timber Press. INC. Portland, Oregon, USA. 101-230.

Fischer, C. et al. (1998): Testing Scab Resistance Stabbility of New Resistant Cultivars within the Apple Breeding Programme. Acta Horticulturae. 484: 449-454.

Fischer, C. et al. (2000): Stabilität der Schorfresistenz an ApfelNeue Ergebnisse, Probleme und Chancen ihrer Erhaltung. Erwerbsobstbau. 42: 73-82.

Fischer, M. (2000): Verwentung mono- und polygenischer Krankenheitsresistenzen in der Obstzüchtung. Erwerbsobstbau. 42: $87-92$.

G. Tóth, M., Rozsnyay, Zs. \& D. X., Quang. (1994): Apple Breeding for Disease Resistance in Hungary. 27-30. in: Schmidt, H., Kellerhals (eds.): Progress in Temperate Fruit Breeding. Kluwer Academic, Dordrecht, Netherlands.

G. Tóth, M., D. X., Quang, Kovács, Sz. \& Kitley, M. (1996): Resistance to scab in apple progenies from resistant and susceptible cultivars. Oxford: Proceedings of Eucarpia Symposium on Fruit Breeding and Genetics. Abstracts: 26.

G. Tóth, M. (1997): Alma. 31-111. in. G. Tóth, M. (szerk.). Gyümölcsészet. Primom Kiadó, Nyíregyháza.

G. Tóth, M., D. Rozsnyay, Zs. \& Kovács ,Sz. (2000): A venturiás varasodással szembeni ellenállóság öröklôdése alma utódnemzedé- kekben - $\mathrm{a} \mathrm{V}_{\mathrm{f}}$ rezisztencia bonyolultsága. Budapest: Lippay JánosVas Károly Nemzetközi Tudományos Ülésszak Gyümölcstermesztési Szekció. Összefoglaló: 262.

Gessler, C. (1992): Scab Resistance in Apple: the Minor Genes in the Vf-resistance. Acta Phytopathologica et Economica Hungarica. 27.1-4: 257-263.

Janick, J. \& Moore, J. N. (eds.) (1996): Fruit breeding. Volume 1. Tree and tropical fruits. New York: John Wiley \& Sons. Inc., $1-77$.

Kellerhals, M., Fouillet, A. \& Lespinasse, Y. (1993): Effect of the scab inoculum and the susceptible parent on resistance to apple scab (Venturia inaequalis) in the progenies of crosses to the scab resistant cv. 'Florina'. Plant pathology. 13: 631-636.

Kellerhals, M., Viviani, A., Goere, M. \& Gessler, C. (1998): New Challenges for Apple Breeding. Acta Horticulturae. 484: $131-134$.

Keulemans, J. et al. (1998): Consideration on the Scab Susceptibility in Apple Breeding. Acta Horticulturae. 484: 507-511.

Kovács, Sz. \& G. Tóth, M. (2002): Új génforrások az alma fổbb betegségeivel (venturiás varasodás, almalisztharmat) szemben ellenálló almafajták nemesítéséhez. Kertgazdaság. 34: 21-32.

Krüger, J., Gasché, B. \& Stielau, E. (1999): Vorkommen der 1 bis 6 auf den Ahrensburger Apfelfeldern. Erwerbsobstbau. 41: 129-130.

Lamb, C. R. \& Hamilton, J. M. (1969): Enviromental and genetic factors influencing the expreession of resistance to scab (Venturia inaequalis Cke. Wint.) in apple progenies. J. Amer. Soc. Hortic. Sci. 94: 554-557.

McHardy, William, E. (1996): Apple Scab, Biology, Epidemology and Management. Minnesota (USA), APS Press. 1-539.

Parisi, L. \& Lespinasse, Y. (1996): Pathogenicity of Venturia inaequalis strains of race 6 on apple clones (Malus ssp.). Eucarpia Symposium on Fruit Breeding and Genetics. Oxford. Abstracts. 20. Schärer, H. J. \& Kellerhals, M. (2000): Schorfdurchbruch bei $V_{f^{-}}$ resistenten Apfelsorten? Obst-Weinbau. 7: 124-126.

Shay, J. R., Dayton, D. F. \& Huogh. L. F. (1953): Apple scab resistance from a number of Malus species. Proc. Amer. Soc. Hortic. Sci. 62: 348-356. 